\title{
Belgeo
}

Revue belge de géographie

1-2 | 2012

Inaugural issue

\section{Stimulating or frustrating research ? Transport geography and (un)available data}

Recherche stimulante ou frustrante? La géographie des transports face aux données (in)accessibles

Frédéric Dobruszkes

\section{(2) OpenEdition}

\section{Journals}

Electronic version

URL: http://journals.openedition.org/belgeo/7082

DOI: 10.4000/belgeo.7082

ISSN: 2294-9135

\section{Publisher:}

National Committee of Geography of Belgium, Société Royale Belge de Géographie

\section{Electronic reference}

Frédéric Dobruszkes, « Stimulating or frustrating research ? Transport geography and (un)available data », Belgeo [Online], 1-2 | 2012, Online since 04 December 2012, connection on 30 April 2019. URL http://journals.openedition.org/belgeo/7082 ; DOI : 10.4000/belgeo.7082

This text was automatically generated on 30 April 2019

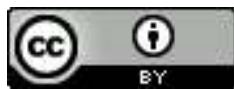

Belgeo est mis à disposition selon les termes de la licence Creative Commons Attribution 4.0 International. 


\title{
Stimulating or frustrating research? Transport geography and (un)available data
}

\author{
Recherche stimulante ou frustrante? La géographie des transports face aux
} données (in)accessibles

Frédéric Dobruszkes

\section{Introduction}

1 Most researchers agree that "transport is inherently spatial" (Shaw et al. 2008, p. 4) and that "transportation is a measure of the relations between areas and is therefore an essential part of geography" (Ullman and Mayer, 1954, p. 311). Yet shifting from "transport" to "transport geography", there are many definitions of what "transport geography' could (or should) do. Transport geography is a widening field ${ }^{1}$ and transport geographers have been working towards two major directions (White and Senior, 1983; Hoyle and Knowles, 1998 ; Shaw et al., 2008). On the one hand, they have produced many works focusing on transport networks, facilities, and services themselves, usually given both physical and human or social constraints and determinants. On the other hand, they have studied the impact of transports on societies, the economy, and the environment. Putting aside works focusing only on transport free of any concerns on interactions with physical and human realities ${ }^{2}$, as well as contemporary reflections on the 'new mobilities paradigm' (Sheller and Urry, 2006) which are often still doing the groundwork without data, we arrive at the following definition of transport geography :

"Transport geography is a sub-discipline of geography concerned about movements of freight, people and information. It seeks to link spatial constraints and attributes with the origin, the destination, the extent, the nature and the purpose of movements." (Rodrigue et al., 2006, p. 5). 
between "spaces" and "transports"; this is revant from the local to the global. In other words, transport geographers should analyse how the milieu produces and constraints transports and how transports impact the milieu they serve or they go through. Transport flows are also used as a proxy to "read the world", namely to estimate more global interactions, for example, airline flows describing interaction between global cities (Derudder and Witlox, 2005).

3 Studying these interactions thus requires data on both spaces and transports. While economists may be pleased with aggregate figures, geographers use spatially disaggregated figures to discover, analyse and interpret spatial variations. Furthermore, even when economists use spatially disaggregated figures, geographers are more interested in crossing them (or the disaggregated results) with various spatial attributes. To give one example, while performing multiple regressions on spatialised data, an economist pays attention to the global results, while a geographer also produces maps with the dependent variable and the regressions' residuals (i.e. deviations from the model) (see e.g. Vandenbulcke et al., 2011). Such cartography may help discovering additional factors as well as highlighting local, regional, national or continental specificities, depending on the scale.

4 Gathering adequate data on both transport and spaces is thus a crucial step for many academic or applied works in transport geography, except perhaps in the case of very theoretical or conceptual research and for those post-modern geographers not confronting their thoughts with figures and evidence. However, I think we are currently experiencing a curious paradox : some data are becoming more easily available, while others are becoming protected by the seal of the commercial secret. This paper examines this paradox more in depth, mainly focusing on Europe and the world scale.

5 The rest of this paper is organised as follows. The next section summarises the main data that are usually needed to analyse interactions between transport and spaces. Section 3 introduces data that have become (un)available and makes the link with modern transport geography. Section 4 gives the conclusions.

\section{Data as a masterpiece for transport geographers}

6 There are of course many ways to perform transport geography and not every scholar needs large quantities of data. Yet in many cases, data on both transport and spaces cannot be ignored to solve a research question or hypothesis. The data related to transport may, should or must concern the emission of flows (for example, how many people commute every weekday from their home at the municipal level), its reception (the municipalities in which commuters work), and/or the involved territories as an origin-destination matrix. Spatial attributes on both places and transports services are required to interpret flows. Let us consider some examples.

7 Consider a researcher who is interested in understanding why some cities are serviced more by airlines than others. The common way to solve this would be to perform a multiple regression linking the volume of air services with spatial attributes related to the cities. These attributes should refer to attributes that are expected to promote air services. Researchers usually consider the urban or metropolitan size (number of inhabitants, employments, GDP, etc.), population or economy attributes (per capita

Belgeo, 1-2 | 2012 
income, employments in tourism, national or international administrative functions, etc.) and additional attributes related to both absolute and relative location (days of sun, Canada effect, distance to the nearest major airport hub, etc.) (Dobruszkes et al., 2011).

Now consider a researcher doing a similar exercise at the city-pair level focusing on passengers rather than on supply. To understand why people are flying on 339 European city-pairs, Jorge-Calderón (1997) gathered both geo-economic and transport-related variables. Geo-economic data refer to the European cities at both end-points of airline routes (inhabitants, regional product) and were controlled by additional geographical or locational factors (distance ; flying over the sea ; proximity of a hub airport). Transportrelated data notably refer to the number of weekly flights and prices. The authors also added 'holiday resort destination' and hub functions as controlling variables.

In contrast, consider a researcher focusing on the potential of building new high-speed lines (HSLs) for high-speed trains (HSTs) with a special focus on mode substitution from airplanes to HSTs in so-called developed countries. Three factors should be reasonably considered as the main constraints : the distance, the number of airline passengers at the city-pair level (which influences the potential market size thus the plausible profitability of a new HSL) and physical barriers like large water areas and mountains that make HSLs too expensive or even technically impossible to build (Givoni et al., forthcoming).

Finally, consider a research focusing on commuters' modal choice. Reviews of the literature reveal that the modal choice is a complex process that depends on many partially correlated factors, namely transport attributes (e.g. door-to-door travel time, cost, service reliability, comfort, etc.), commuters attributes (social class, education, age, gender, car availability, incomes, perceptions, trip chain complexity, etc.), milieus in which they are both living and working (density, security, parking facilities, etc.), employment constraints (for example unpredictable or fluctuant timetables) and employer strategies (parking uses, company cars, contribution to travel expenditures, etc.) (De Witte et al., 2011). Distance also plays a role given that walking or cycling would only be possible on shorter trips. Trains seem 'overused' for longer trips, probably because this mode is often regarded as less tiring and allows time for reading, working or resting. Analysing the modal choice thus would require many data related to transport, places, people and employers referring to origins, destinations and routes.

11 From these few examples, it can be easily understood that data useful for transport geographers are related to transport and non-transport attributes. Transport attributes may refer to infrastructure networks, the supply - i.e. transport services, networks' or facilities' capacity, car availability, etc.- or the demand -i.e. the passengers, goods or information moving from one place to another one. Non-transport attributes refer to spaces generating and/or attracting flows as well as covered by them. These nontransport attributes refer to four fields :

- The accumulations, namely the stocks (of inhabitants, employments, gross domestic product, tourist facilities, etc.) that indicate the potential market size.

- The characterisation of these stocks (socio-economic attributes, economic structure, etc.) that influence the propensity to travel, travel purpose, destinations choices, modal choice, etc.

- The distance whose the various meanings (straight-line distance, time-distance, cognitivedistance, etc.) remain "a fundamental factor in determining real-world relationships" and "is a central theme in geography" even "[its] effects are not uniform" (Knox et Marston, 2007); it has been argued that distance should probably be reinvestigated by transport geographers 
(Banister, 2011). In other words, "Origin-destination matrices have fascinated regional science researchers for many decades and have been the object of abundant academic literature studying the impact of distance on the intensity of flow between origin and destination" (Blondel et al., 2010).

- Physical constraints that should not be underestimated, especially for those transport modes sensitive to the relief and waters (given the cost of tunnels) and/or the weather. and characterisation of stocks.

\section{From (un)available data to current research in transport geography}

13 Finding and accessing information has been revolutionised by the general use of the Internet. When I was conducting my MA thesis in 1995, obtaining any annual report required calling the editing firm or administration, waiting several days, and then, when relevant, encoding the required figures for further analyses. Today, numerous reports and databases can be easily downloaded online. At the same time, however, various data sets have become confidential. This section presents general trends and examples.

\section{Infrastructure networks}

Infrastructures have often become easier to locate, especially if they are public or well visible in the landscape. Linear infrastructures (roads, railways, canals, etc.) are part of public cartography that has become digital. It has become possible to buy so-called (digital) shapes, though they might be expensive. Various private firms also provide georeferenced data at various scales. For example, Tele Atlas (now acquired by Tom Tom) produces a Belgian package of shapes that notably includes a precise location of railway lines and main roads, allowing for example easy buffering functions. Terminal infrastructures (ports, railway or underground stations, airports, etc.) are more and more freely available from the Internet either as a shape or as databases with geographic coordinates.

Public transport companies have modernised their management, so their infrastructures are now often fully digital and integrated into global systems. Depending on the policy, these companies are potentially useful providers of geo-referenced data. The same occurs with local or regional authorities setting a GIS that includes transport infrastructures or services. For example, UrbIS (Brussels Urban Information System) includes data on underground infrastructure, access to the stations, tram lines and stops and railway lands.

Finally, Google Earth may be useful to update or check existing shapes, or even to build them for small networks. Indeed, this software allows one to draw literally on its Earth views. For example, a researcher interested in, say, the tram network of Marseilles (12 $\mathrm{km})$ could save time digitising it himself rather than taking steps to obtain it from the operator or the local authorities; yet this work should then be converted into the right cartographic coordinates (an exercise that requires some projections skills).

17 All of this allows infinite analyses using for example graph theory and GIS functions (see Ducruet and Lugo, forthcoming, for a review). For example, Dupuy and Stransky (1996) compute the hierarchy of cities in the European highway network. Derrible and Kennedy 
(2009) perform an analysis of 19 underground systems' network design, computing transit coverage, directness and connectivity. Derrible and Kennedy (2010) expand their work to 33 underground networks and more indicators, including complexity (current development phase) and integration in the built environment (regional accessibility, local coverage or regional coverage).

In contrast, terminal infrastructures remain more tiresome to identify if they are private. Thus, focusing on logistic supply chains in Europe, Strale (2010) built from scratch its own database on these facilities, a laborious and time-consuming task, as a starting point for further geographical analysis.

\section{Transport services}

Transport geographers are often more interested in services than the infrastructure supporting them. Scheduled services (routes, timetables, frequency, capacity, fares, etc.) have become easier to investigate thanks to databases produced by national or international administrations, lobbies and private firms. Eurostat, International Union of Railways (UIC), International Association of Public Transport (UITP), International Civil Aviation Organization (ICAO), British Civil Aviation Authority (CAA), Official Airline Guide (OAG), TeleGeography, etc. provide many databases on services that complete other paper-only editions (such the Thomas Cook European Rail Timetable). These databases may include time series for more than two decades. The main problem here is the reserved access (e.g. for member companies) and/or the cost. For example, OAG monthly provides spatially disaggregated and exhaustive, worldwide data on scheduled air services. Before negotiation, the fares for a single academic user were EUR 3,500 for a unique monthly CD edition or EUR 10,750 for an annual online subscription including access to the ICAO traffic data and reports (plus VAT).

For those accessing these data, the range of research questions is nearly infinite. Thus, disaggregated OAG's time series on air services have allowed comprehensive works on the dynamic of airline networks. They were extensively used by Burghouwt (2007) and Dobruszkes (2008) at the European scale in the aftermath of air transport liberalisation. The range of potential research is linked to the range of variables provided in the databases. The fact that the OAG dataset includes timetables allows for research into the temporality of airline services and the connections between them (see Burghouwt and de Wit, 2005). Information on the airline(s) operating each flight allows for the analysis of how different airlines (according their initial size, their business model, their nationality, the places they serve, etc.) have responded to the liberalisation process. It also allows for measuring competition at the route or airport level, whether low-cost airlines have a specific geography, which airlines have operated the Public Service Obligations that are not concerned by liberalisation, etc. (Dobruszkes, 2008). For maritime transport, service data from main container shipping lines are available from Containerisation International Yearbooks and have been used by Frémont (2007) to describe the port network of Maersk on the world map. Following their discussion on the difficulty of accessing relevant and disaggregated data on maritime flows, Ducruet et al. (2010) provided an analysis of vessel movements across the Atlantic using clustering methods. However, even with expensive databases, time series covering a large period are unusual. For example, the comprehensive OAG dataset starts in 1991; going through the open archives remains the only way to obtain older data. For example, Bretagnolle's et al. 
(2010) work on the evolution of the horse postal roads in the pre-industrial France as well as Wang et al. (2009) looking at space-time accessibility changes in the Chinese railway network since 1911 (see also a 2009 special issue of Networks \& Spatial Economics on the evolution of transportation network infrastructure).

For the numerous scholars who cannot afford costly datasets, the Internet may be a second-best solution. Using transport companies or more global engines, it is easy to obtain some basic information on services. However, this is insufficient for any research aimed at covering more than city-pairs, since this method is time consuming, and only information on current or short-term services are available. On the other hand, websites may be helpful for obtaining information on fares according to company profiles (for example a low-cost airline versus a conventional one) or various passenger profiles according to their flexibility on schedules and on advance vs. late booking.

A last option, which usually fits well with a focus on a specific network, is to obtain the information directly from the transport company. The propensity to give data often depends on commercial concerns (especially within a liberalised market) and the company's interest. For example, scholars interested in information from Ryanair, the main European low-cost airline, can only fill out a form on the Internet to request information. Then the airline decides to give a reply or not (my own requests always remained unanswered). In contrast, Courtois (2007) received full access to fully disaggregated data on inter-stop travel times from the Brussels main public transport operator (STIB). This allowed him to perform a comprehensive and spatially disaggregated analysis, computing and mapping commercial speed, irregularity and time lost by the buses and trams in a day, thus locating the main problems. Of course, the STIB was interested in the results. As a public, monopolistic operator, however, it is more cooperative than most private companies. The recent first step of the Brussels Observatory on Mobility (Lebrun et al., forthcoming) demonstrates how much data on transport infrastructures and services exist; however, they are spread among administrations and transport operators and are not always retrievable or easy to handle.

In contrast, data on non-scheduled services are often sparse or missing. In his MA thesis on charter flights from five European countries at the city-pair level, Schepens (2004) had no other choice to contact all concerned airlines to obtain as much data as possible. He mainly obtained routes (origin-destination) flown and aircrafts used. Only his own knowledge of the airline industry allowed him to convert this information into the volume of seats supplied.

\section{Transport demand}

While supply can often be analysed depending time and/or money available for research, things get even more complicated concerning the demand, i.e. passengers, goods and information carried. Any transport geographer would be happy to know where, why, how, and how often. Actually, the demand is or has become a black box. Of course, costly data are provided by most of the same aforementioned sources as well as by the World Bank on international trade and freight transport. Of course it is rather easy to find the number of passengers or tons carried by a company supplying scheduled services or to/ from a given port or airport. Of course national censuses may give indications on daily mobilities, especially to work or to school. However, there are several limitations. First, available data are mainly aggregated. A transport company might provide its global 
volume of traffic but not by city-pair or even country-pair. The reason is very simple : competition following liberalisations has made data on the demand a highly strategic, commercial secret. For example, it is really impossible to obtain an inter-city matrix of rail passengers from the French railways, despite the fact that it is a public company running its trains on public tracks largely financed by taxpayers.

With increasing competition, transport companies and other data suppliers tend to curb their data. Thus, the ICAO sells various interesting data on airline traffic, but these data remain aggregated to preserve a certain degree of confidentiality. For example, the volume of passengers, freight and mail tons is only available for international city-pairs and without distinction by airline (despite it costs from $\$ 1,600$ ). This prevents, for example, analysing whether low-cost airline passengers have a specific geography compared to conventional airlines. The British CAA provides free, monthly comprehensive data on passenger volumes for any city-pair involving a British airport ${ }^{3}$. This is rare and very useful, but unfortunately these data only make the distinction between scheduled and charter companies.

Census data are sometimes available but again at an aggregated level (districts or municipalities) ; individual data would be better to avoid ecological fallacy. Due in part to privacy concerns, individual data allowing us to cross daily mobilities and various individual or household attributes are often unavailable. Furthermore, censuses may be insufficient to address an issue, even on mobilities they covered. For example, studying carpooling in Belgium, Vanoutrive et al. (2012) use data from the 2001 census to present a general, comprehensive outlook and the 2005 Belgian database on home-to-work travels, which covers these flows and mobilities management set out by the main employers, to study the determinants of this practice.

National or metropolitan household surveys on mobilities may be interesting, especially for focusing on all mobilities rather than only on daily mobilities. This allows us to investigating trends in (and factors of) long-distance and tourist or VFR (visit to friends and relatives) mobilities (for example, see Longuar et al. (2010) for France, Frändberg and Vilhelmson (2011) for Sweden; Dargay and Clark (2012) for the UK). However, sampling constraints may limit the extent to which data can be crossed.

Finally, traffic on non-scheduled services remains largely unknown for passengers and freight, except at a global level. This helps to understand why "in recent decades transport geography has been transformed by a topical emphasis towards passengers" (Rodrigue, 2006). Sometimes, other national figures are available that allow comprehensive analysis of changes in the demand. For example, Mondou (2010) uses Moroccan data on air passenger arrival derived from the ingoing form that any passenger must fill at customs. This allowed her to analyse how the new low-cost airline services have impacted trips to Morocco, distinguishing business, tourists and VFR travellers as well as Moroccan migrants and others.

30 Admittedly, when global data on services are available, the supply is sometime used as a proxy for the demand. However, it raises methodological concerns (see, for example, Derudder and Witlox, 2008) ${ }^{4}$. In addition, new technologies may help to trace flows. For example, urban road pricing and smart cards are used more and more often in urban public transport, which allows infrastructure or transport companies to record various information (date, time, ingoing and sometime outgoing points) that can be linked with user profiles (as many supermarkets or other chains do). Yet, there are major privacy 
concerns that make use of this type of data very sensitive, depending on the country. GPS can be also used to trace mobilities. For example, Neves (2012) uses them to detect whether a new bridge dedicated to cyclists and pedestrians in Cardiff has induced changes in both trips and routes. Although this is a powerful means to follow people travelling, the material can only be used to study a sample. Smartphones including GPS could simplify the procedure, but privacy concerns and potential bias remain, since not all social groups own smartphones at the moment.

In this context, many works focus on study cases, while some authors make ambitious plan without any data or evidence. For example, there are more and more authors writing on elites' international mobilities, although mainly without empirical material. To challenge this, Berroir et al. (2009) have surveyed hundreds of international travellers living in Berlin, Brussels, London and Paris to highlight a variety of reticular organisations. Another interesting issue is whether barrier effects due to international borders remain within an integrated area, for example, the EU. While this should call for a comprehensive analysis including a look at both positive and negative deviations from the trend, works usually focus on a specific case, for example, Knowles and Matthiessen (2009) on the Øresundsbron. Airline passengers were totally absent of my doctorate on the liberalisation of the European air transport, because I only received time series on worldwide air services and aimed to work comprehensively ${ }^{5}$. The context is even more tragic concerning freight, with adequate data usually missing. Many authors analyse supply chains or logistic facilities without any concrete examples or comprehensive analysis.

Given this context related to both supply and demand, a double gap has taken place among transport geographers, as is clearly visible going through the 153 full papers published in 2011 by the Journal of Transport Geography. On the one hand, transport geographers are focusing more on demand than on infrastructures and supply. Among these 153 papers, 57 are clearly linked to demand, 34 to supply ; additional papers are linked to infrastructures (23), other themes (29) or various combinations (10). On the other hand, almost all of these works focusing on the demand tend are limited to study cases, i.e. limited spaces, selected carriers or a sample of carried people or goods. Among the 57 aforementioned papers, only 5 can be considered as comprehensive or global. The others are limited to study cases or do not use data at all.

In this context, major changes in flows may be unknown. For example, there is little evidence on the origin of high-speed rail passengers in Europe distinguishing induced traffic, mode change, etc. (Dobruszkes and Givoni, 2012). Only market shares in percents are available, without any indication of the change in the absolute size of the market, except in some case studies. The same gap occurs with the new French trams: anyone is able to state if their ridership comes from cars or from induced traffic; thus, an environmental assessment is not possible. Another example is the boom of low-cost airlines in many regions, notably in Europe. While Ryanair is now the number-one European airline according to the number of passengers, we do not know who its passengers are, how or why they travel, whether they were travelling before, how they impact involved territories, etc. except in case studies (for example Donzelli, 2010) sometimes purely qualitative (for example Burrell, 2011). 


\section{Accumulations and characterising the stocks}

34 undeniable. On a national basis, census results are sometime fully, freely and easily available through the Internet at the district (infra-municipal) level, as is now the case in France. This opens a wide range of research questions that involve crossing data on transport and their milieu. For example, de Spiegeleire and Evens (2010) focus on the socio-economic changes potentially induced by the new trams in Strasbourg and Montpellier using census data freely retrieved from the Internet. De Leeuw (2011) analyse which social groups are served by the new trams in 11 French cities. He built a socioprofessional typology of the inhabitants using the 2007 census, which was easily retrieved from the Internet. He also digitalised the networks in Google Earth and then created buffers to select the concerned so-called Iris districts. For each city, he states if the social pattern of the served districts corresponds to the average social pattern of the whole city. This rather basic research (although time-consuming) had never been done before. This exciting research contrasts with the fact that we know almost nothing on these modern trams' ridership.

Accumulation and socio-economic characteristics of spaces are often easier to obtain at the national level thanks to international organisations. Thus, having previously bought data on airline services, Dobruszkes and Van Hamme (2011) can easily cross changes in air services with changes in GDP obtained from the IMF to analyse the impact of the current economic crisis. International comparisons at the urban or regional level remain difficult, but regional integrations tend to offer standardised materials, as the European case demonstrates. European integration has lead Eurostat to gather nationwide or regional data that may be interesting for the researcher. Even more stimulating works have been achieved within the European Spatial Planning Observation Network (ESPON) program. For example, morphological and functional urban areas (MUAs/FUAs) have been demarcated through a homogenous method, and various data on both metropolitan size and functions have been gathered. Although these data are not automatically available for anyone, they also open new perspectives for transport geographers interested in European studies. For example, Dobruszkes et al. (2011) used them to perform a multiple regression focused on the analysis of the determinants of air traffic volume for 113 European metropolitan areas. Such analysis has been done for a long time in the US context (see e.g. Liu et al. 2006) thanks to national (and thus homogenous) statistics. As for Europe, it seems that only Cattan (1995) has performed this before, covering the EU12.

\section{Concluding remarks}

As a traditional transport geographer, I believe that data are crucial in transport geography. This is not only because this sub-discipline has usually been, at least in the Anglo-Saxon world, more quantitative than qualitative (Goetz et al., 2009). Surprisingly, recent viewpoints have not addressed this (Goetz, 2006; Rodrigue, 2006; Keeling, 2007 ; etc.). Thus, for those geographers still interested in using evidence -thus data-, there are divergent trends, with data on both transport and spaces becoming unavailable or available. There is a black box on demand, freight transport and non-scheduled services. 
There are advances in infrastructures, services and non-transport databases, but they remain expensive and not open to everyone. For many researchers, this implies spending a lot of time gathering information for what could be case studies focusing on limited spaces, specific segments, etc. Thus, research in transport geography can be stimulating for some and frustrating for others.

However, I am convinced that data are more than ever necessary, at least in three ways. First, we are experiencing a changing and post-Fordist world with new industrial locations worldwide, regional and global integrations, emerging countries with new middle and upper classes, decrease in transport costs, social changes for example in urban cities notably through gentrification process in central areas, expansion of edge cities, progressive liberalisation of transport services, decrease of the welfare state and public services, etc. This involves potential changes in the geography of all flows at all scales. Only large amounts of data could help to determine whether and to what extent flows and relations between flows and spaces have changed.

Second, I agree with Goetz et al. (2009) that transport geographers should open up to a more critical, transport geography. In the recent literature, they identified themes like the new mobilities paradigm ; global production networks, commodity and supply chains, and the logistic and distribution industry; as well as social and environmental justice. One should also consider linking transport geography and critical social theories, as it is more evident for political or economic geographers. For example, a radical transport geography has never been set, despite the aforementioned and contemporary concerns within this realm of critical geography. Be that as it may, I also agree with Goetz et al. (2009) that critical transport geography should not only be qualitative, as has been mainly the case until now. At the time it is recognised that "critical geographies cannot dispense with numbers and visualizations based on numerical information" (Schwanen and Kwan, 2009), it would be regrettable that transport geographers miss the boat.

Finally, data should also support new theories on flows and mobilities. Of course we must be open to new visions on flows and their interactions with spaces and societies. For example, the new mobilities paradigm states that moving is broader than simply carrying people or things from A to B (Shaw and Hesse, 2010). However, too many things are put forth without evidence or are based only on very limited figures and case studies. Using (comprehensive) data, transport geographers could appropriate part of this new mobilities paradigm to make it more concrete and could establish transport geography as a concrete sub-discipline, linking spaces and flows, using concepts, methods and techniques from various disciplines and remaining well connected to contemporary issues and policy-related concerns. Adequate use of data, as a means and not as an end, should definitively differentiate a modern transport geographer and post-modern attitudes. Of course, we also need researchers who, as the philosophers often do, do the groundwork in a changing environment on neglected topics. Yet this should only be a starting point, and not a "refuge". To give one example, the recent progress of transport geographers focusing on time demonstrate that it is possible to combine progress in transport geography, methodological developments and empirical support (see e.g. Alexander et al., 2011 ; Neutens et al., 2010a and 2010b).

In practical terms, data should be more available for researchers. Public authorities play a fundamental role here. They already hold plenty of data that could be made available for research purposes while protecting privacy. They also have the power to force transport companies to send data on a harmonised basis, as the European Union has done for 
airport traffic. They could also force public transport companies to open their archives and make current data available. International public organisations should also be more flexible, cutting prices and declassifying older data. All this would really guarantee stimulating transport geography.

\section{Acknowledgements}

This research is part of the DATE project, financed by the European Commission under a Marie Curie Intra-European Fellowship for Career Development. It only reflects the author's view and the European Union is not liable for any use that may be made of the information contained therein.I also thank César Ducruet (CNRS, UMR Géographie-cités) for his useful comments on earlier versions of this paper, any remaining errors and misinterpretations being my own.

\section{BIBLIOGRAPHY}

ALEXANDER B., HUBERS C., SCHWANEN T., DIJST M., ETTEMA D. (2011), “Anything, anywhere, anytime? Developing measurement instruments to assess the spatial and temporal fragmentation of activities", Environment and Planning B : Planning and Design, 38, 4, pp. 678-705.

BANISTER D. (2011), “The trilogy of distance, speed and time”, Journal of Transport Geography, 19, 4, pp. 950-959.

BERROIR S., CATTAN N., DECROLY J.-M., FLEURY A., GUÉROIS M. (2009), “Les mobilités internationales en Europe. Berlin, Bruxelles, Londres et Paris dans les nouveaux réseaux territoriaux", Géocarrefour, 84, 3, pp. 151-161.

BLONDEL V., KRINGS G., THOMAS I. (2010), "Regions and borders of mobile telephony in Belgium and in the Brussels metropolitan zone", Brussels Studies, 42, pp. 1-12.

BRETAGNOLLE A., GIRAUD T., VERDIER N. (2010), “Modéliser l'efficacité d'un réseau : le cas des routes de poste en France (1632, 1833)", L'Espace Géographique, 39, 2, pp. 117-131.

BURGHOUWT G. (2007), Airline Network Development in Europe and its Implications for Airport Planning . Hampshire, Ashgate.

BURGHOUWT G., de WIT J. (2005), “Temporal configurations of European airline networks”, Journal of Air Transport Management, 11, pp. 185-198

BURRELL K. (2011), “Going steerage on Ryanair : cultures of migrant air travel between Poland and the UK", Journal of Transport Geography, 19, 5, pp. 1023-1030.

CATTAN N. (1995), "Attractivity and internationalisation of the major European cities : the example of air traffic”, Urban Studies, 32, 2, pp. 303-312.

COURTOIS X. (2007), Géographie de la vitesse commerciale sur le réseau de la STIB, ULB, unpublished MA thesis in Geography, $166 \mathrm{p}$.

DARGAY J., CLARK S. (2012), “The determinants of long distance travel in Great Britain”, Transportation Research Part A, 46, 3, pp. 576-587

DE LEEUW C. (2011), Le renouveau du tramway en France: Type de population desservie par ces nouveaux tramways, ULB, unpublished MA thesis in Geography. 
de SPIEGELEIRE Y., EVENS M. (2010), Les "effets structurants" du tramway en France : étude de cas de la ville de Strasbourg et de Montpellier, ULB, unpublished MA thesis in Geography.

DE WITTE A., HOLLEVOET J., HUBERT M., DOBRUSZKES F., MACHARIS C. (2011), Which

determinants influence modal choice? A review towards a better understanding of travel behaviour, paper presented at the NECTAR conference, Antwerp.

DERRIBLE S., KENNEDY C. (2009), "Network Analysis of World Subway Systems Using Updated Graph Theory", Transportation Research Record : Journal of the Transportation Research Board, 2112, pp. 17-25.

DERRIBLE S., KENNEDY C. (2010), “Characterizing metro networks : state, form, and structure”, Transportation, 37, pp. 275-297.

DERUDDER B., WITLOX F. (2005), “An Appraisal of the Use of Airline Data in Assessing the World City Network : A Research Note on Data”, Cities, 42, 13, pp. 2371-2388.

DERUDDER B., WITLOX F. (2008), “Mapping global city networks through airline flows : context, relevance, and problems", Journal of Transport Geography, 16, 5, pp. 305-312.

DOBRUSZKES F. (2008), Libéralisation et desserte des territoires : le cas du transport aérien européen, Peter Lang, coll. Action publique, 285 p.

DOBRUSZKES F., GIVONI M. (2012), In search of evidence for mode shift and induced demand following HSR development - an international perspective, Paper presented at the 2012 UTSG Annual Conference, Aberdeen.

DOBRUSZKES F., LENNERT M., VAN HAMME G. (2011), “An analysis of the determinants of air traffic volume for European metropolitan areas”, Journal of Transport Geography, 19, 4, pp. 755-762.

DOBRUSZKES F., VAN HAMME G. (2011), "The impact of the current economic crisis on the geography of air traffic volumes : An empirical analysis", Journal of Transport Geography, 19, 6, pp. 1387-1398.

DONZELLI M. (2010), “The effect of low-cost air transportation on the local economy : Evidence from Southern Italy”, Journal of Air Transport Management, 16, 3, pp. 121-126.

DUCRUET C., ROZENBLAT C., ZAIDI F. (2010), "Ports in multi-level maritime networks : Evidence from the Atlantic (1996-2006)", Journal of Transport Geography, 18, 4, pp. 508-518.

DUCRUET C., LUGO I. (forthcoming), "Structure and dynamics of transportation networks", in RODRIGUE J.-P., NOTTEBOOM, T., SHAW J. (eds.), The SAGE Handbook of Transport Studies.

DUPUY G., STRANSKY V. (1996), “Cities and highway networks in Europe”, Journal of Transport Geography, 4, 2, pp. 107-121.

FRÄNDBERG L., VILHELMSON B. (2011), "More or less travel : personal mobility trends in the Swedish population focusing gender and cohort", Journal of Transport Geography, 19, 6, pp. 1235-1244.

FRÉMONT A. (2007), "Global maritime networks : the case of Maersk", Journal of Transport Geography, 15, 6, pp. 431-442.

GIVONI M., DOBRUSZKES F., LUGO I. (forthcoming), "Uncovering the Real Potential for Air-Rail Substitution : An Exploratory Analysis”, in INDERWILDI O., KING D. (eds.), Energy, Transport, \& the Environment, Addressing the Sustainable Mobility Paradigm, Springer.

GOETZ Z. (2006), “Transport Geography : Reflecting on a subdiscipline and identifying future research trajectories. The insularity issue in Transport Geography", Journal of Transport Geography, 14,3 , pp. 230-231 
GOETZ A., VOWLES T., TIERNEY S. (2009), "Bridging the Qualitative-Quantitative Divide in Transport Geography”, The Professional Geographer, 61, 3, pp. 323-335.

HOYLE B., KNOWLES R. (1998), “Transport geography : an introduction”, in HOYLE B., KNOWLES R., Modern Transport Geography, $2^{\text {nd }}$ edition, Chichester, Wiley, pp. 1-12.

JORGE-CALDERÓN J. D. (1997), “A demand model for scheduled airline services on international European routes”, Journal of Air Transport Management, 3, 1, pp. 23-35.

KEELING D. (2007), “Transportation geography : new directions on well-worn trails”, Progress in Human Geography, 31, 2, pp. 217-225.

KNOWLES R. (1993), "Research agendas in transport geography for the 1990s", Journal of Transport Geography, 1, 1, pp. 3-11.

KNOWLES R., MATTHIESSEN C. (2009), "Barrier effects of international borders on fixed link traffic generation : the case of Øresundsbron”, Journal of Transport Geography, 17, 3, pp. 155-165.

KNOX P., MARSTON S. (2007), Places and regions in global context - Human geography, Upper Saddle River, Pearson/Prentice Hall, 537 p.

LEBRUN K., HUBERT M., DOBRUSZKES F., HUYNEN P. (forthcoming), "Se déplacer à Bruxelles : les données de base. La population bruxelloise, l'offre de transport et l'accessibilité de la ville", Cahiers de l'Observatoire de la mobilité de la Région de Bruxelles-Capitale $\mathrm{n}^{\circ} 1$.

LIU Z.-J., DEBBAGE K., BLACKBURN B (2006), “Locational determinants of major US air passenger markets by metropolitan area", Journal of Air Transport Management, 12, 6, pp. 331-341.

LONGUAR Z., NICOLAS J.-P., VERRY D. (2010), “Chaque Français émet en moyenne deux tonnes de $\mathrm{CO} 2$ par an pour effectuer ses déplacements", La Revue, Commissariat général au développement durable - Service de l'observation et des statistiques, pp. 163-176.

MONDOU V. (2010), Les conséquences de la croissance de l'offre aérienne au Maroc sur son développement touristique, paper presented at the 'Transport et développement des territoires' conference, Le Havre.

NEUTENS T., SCHWANEN T., WITLOX F., DE MAEYER P. (2010), "Evaluating the temporal organization of public service provision using space-time accessibility analysis”, Urban Geography, 31, 8, pp. 1039-1064.

NEUTENS T., VERSICHELE M., SCHWANEN T. (2010), “Arranging place and time : a GIS toolkit to assess individual and joint accessibility to urban opportunities”, Applied Geography, 30, 4, pp. 561-575.

NEVES A. (2012), A GPS based methodology to evaluate change in travel behaviour and carbon emissions following implementation of infrastructure for pedestrians and cyclists : a Cardiff Connect2 case study, paper presented at the 2012 UTSG Annual Conference, Aderbeen.

RODRIGUE J.-P. (2006), “Transport geography should follow the freight”, Journal of Transport Geography, 14 5, pp. 386-388

RODRIGUE J.-P., COMTOIS C., SLACK B. (2006), The Geography of Transport Systems, London, Routledge, $284 \mathrm{p}$.

SCHEPENS V. (2004), Analyse de l'offre charter à partir de cinq pays européens, unpublished MA thesis in Tourism, Université Libre de Bruxelles, $84 \mathrm{p}$.

SHAW J., KNOWLES R., DOCHERTY I. (2008), “Introducing Transport Geographies, in KNOWLES R., SHAW J., DOCHERTY I., Transport Geographies, Oxford, Blackwell, pp. 3-9. 
SHAW J. HESSE M. (2010), “Transport, geography and the 'new' mobilities”, Transactions of the Institute of British Geographers, 35, 3, pp. 305-312.

SHELLER M., URRY J. (2006), “The new mobilities paradigm”, Environment and Planning A, 38, 2, pp. 207-226.

SCHWANEN T., KWAN M.-P. (2009) : “'Doing' Critical Geographies with Numbers”, The Professional Geographer, 61, 4, pp. 459-464.

STRALE M. (2010), “La localisation des entreprises logistiques et le positionnement des régions urbaines nord-ouest européennes”, Belgeo, XI, 1-2, pp. 119-133.

ULLMAN E., MAYER H. (1954), “Transportation Geography”, in JAMES P. \& LONES C. (eds.), American Geographiy : Inventory and Prospect, Syracuse, Syracuse University Press, pp. 311-332.

VANDENBULCKE G., DUJARDIN C., THOMAS I., DE GEUS B., DEGRAEUWE B., MEEUSEN R., INT

PANIS L. (2011), "Cycle commuting in Belgium : Spatial determinants and 're-cycling' strategies", Transportation Research Part A : Policy and Practice, 45, 2, pp. 118-137.

VANOUTRIVE T., VAN DE VIJVER E., VAN MALDEREN L., JOURQUIN B., THOMAS I., VERHETSEL A., WITLOX F. (2012), "What determines carpooling to workplaces in Belgium : location, organisation, or promotion ?", Journal of Transport Geography, 22, 2, pp. 77-86.

WANG J., JIN F., MO H., WANG F. (2009), "Spatiotemporal evolution of China's railway network in the $20^{\text {th }}$ century: An accessibility approach", Transportation Research Part A, 43, 8, pp. 765-78.

WHITE H. P., SENIOR M. L. (1983), Transport Geography, London, Longman, 224 p.

\section{NOTES}

1. Both the diversity and the potential are well rendered by the 22 volumes of the Journal of Transport Geography, launched in 1993, and its inaugural editorial (Knowles, 1993).

2. Whether old, descriptive works (primitive transport geography) or some quantitative works, the authors are more excited by the methods themselves than by a broader social science research agenda.

3. Tables 12.1 and 12.2 under UK Airport Statistics (http://www.caa.co.uk/airportstatistics).

4. For example, a service between A and B may be used by passengers going on to $C$ with a connecting service. Another common problem is how to affect the seats between cities on a service from A to D also calling at B and C. Potential trips are A-B, A-C, A-D, B-C, B-D and C-D.

5. This follows a well-established tradition in the research unit to which I belonged at the time.

\section{ABSTRACTS}

This paper addresses the concern of data in line with transport geography. Focusing mainly on data availability, it highlights how data on both transport and spaces are important to transport geography. More and more data are becoming available on infrastructures and scheduled services, although often expensive, and on spaces. In contrast, non-scheduled services, freight transport and the demand remain or are becoming largely unknown. This opens and closes doors 
to transport geographers, paradoxically at the time when post-modernist postures tend to despise figures.

Ce papier s'intéresse au problème des données en rapport avec la géographie des transports. En se focalisant surtout sur leur disponibilité, il montre combien les données tant sur les transports que sur les territoires concernés sont importantes pour la géographie des transports. De plus de en plus de données concernant les infrastructures, l'offre de transport réguliers et les territoires deviennent disponibles, bien que sans être nécessairement financièrement abordables. Par contre, les services non-réguliers, le transport de marchandises et plus généralement la demande de transport demeurent largement méconnus voire deviennent inconnus. Cette double dynamique ouvre et ferme des portes aux géographes des transports, paradoxalement à une époque où les postures postmodernes tendent à négliger les chiffres.

\section{INDEX}

Mots-clés: géographie des transports, mobilités, données transports, disponibilité des données, clivage qualitatif/quantitatif, paradigme "nouvelles mobilités"

Keywords: transport geography, mobilities, transport data, data availability, qualitativequantitative divide, new mobilities paradigm

\section{AUTHOR}

\section{FRÉDÉRIC DOBRUSZKES}

Post-doc researcher, Transport Studies Unit, Oxford University, South Parks Road, Oxford OX1 3QY (UK), +44 (0)1865 2855 38, frederic.dobruszkes@ouce.ox.ac.uk 